\title{
Climate change risk assessment for the Republic of Korea: developing a systematic assessment methodology
}

\author{
Young-II Song ${ }^{1} \cdot$ Seunghan Lee ${ }^{2}$ (1)
}

Received: 17 February 2021 / Revised: 12 October 2021 / Accepted: 30 November 2021 / Published online: 18 December 2021

(c) The Author(s) 2021

\begin{abstract}
Climate change risks have become a major concern of climate change adaptation, and a systematic risk assessment is required as the first step as well as a key principle of national adaptation policy processes. Although many countries conducted risk assessments, a debate over a systematic assessment process continues, and results of the risk assessment provide limited information to making adaptation policies. Based on a case study of South Korea, this research aims to establish a national-level risk assessment process which includes systematic methodologies given the current limited time/resource and insufficient climate change information. A four-step risk assessment process is proposed: (1) collecting scientific evidence, (2) making list of preliminary risks, (3) making lists of risks and prioritising the risks, (4) categorising the risks. Enough scientific evidence and data about climate change risks of Korea were retained through first two steps, and three components of risk (hazard, exposure, vulnerability) are systematically involved by assessing the magnitude and adaptive capacity of risks. As results of the risks assessment, 93 national-level climate change risks of Korea are identified, and most high priorities in risks have high risk magnitude but low adaptive capacity. This research provided insights for direction of national adaptation policy of each sector by categorising the risks into four categories.
\end{abstract}

Keywords Climate change ecological impact $\cdot$ Ecological risk assessment $\cdot$ Risk prioritisation $\cdot$ Risk categorisation · Adaptation policy

\section{Introduction}

Climate change gives rise to cascading risks in human and natural systems (IPCC 2014; Adger et al. 2018). Given that the inevitable impacts of climate change caused by greenhouse gases (GHGs) already emitted, a need for adaptation has increased and the climate change risks have become a major concern of the adaptation (CCC 2017a). Since the Intergovernmental Panel on Climate Change (IPCC)'s Special Report on Extreme Events (SREX) (2012), the concept of climate change risk involves the climate science aspect that projects the probability of a hazard and the dynamic

Seunghan Lee

eeslee@leeds.ac.uk

Young-Il Song

yisong@kei.re.kr

1 Korea Adaptation Centre for Climate Change, Korea Environment Institute, Sejong, South Korea

2 Sustainability Research Institute, School of Earth and Environment, University of Leeds, Leeds, UK socio-economic aspects that drive exposure and vulnerability (IPCC 2012; Adger et al. 2018). IPCC (2014) defines risk as below.

"The potential for consequences where something of value is at stake and where the outcome is uncertain, recognising the diversity of values. Risk is often represented as a probability of occurrence of hazardous events or trends multiplied by the impacts of these events or trends occur. Risk results from the interaction of vulnerability, exposure, and hazard."

Based on climate scientific evidence, hazards (heavy precipitation, tropical cyclone, droughts, floods, heatwaves, sea level rise and etc.) are projected to increase, and the severity of the impacts of the hazards relies strongly on the level of exposure and vulnerability to the hazards (IPCC 2012). IPCC (2014) also highlighted the paradigm shift from vulnerability assessment to risk assessment in their fifth assessment report.

Risk assessment is a crucial source of information and a key principle of managing risks and adaptation policies 
(European Commission 2010, 2013; Papathoma-Köhle et al. 2016; EEA 2018). Decision-makers, under significant uncertainties, should make decisions to address climate change risks. As the process of examining available information to guide decision-making (WRI 2009), risk assessment systematically evaluates potential impacts of hazards and their societal consequences (Morgan et al. 1990; Brown 2015). It is a process to understands the nature and determines the level of risk (Byrd and Cothern 2000; Adger et al. 2018) and provides the basis of an analysis of risk reduction strategies. It is required that risks assessments are regularly conducted, reflecting the change of the risk as hazard, exposure, and vulnerability are continuously changing due to climate and social-economic circumstances' changes (Papathoma-Köhle et al. 2016). At the national level, climate change risk assessments usually aim to make adaptation policies (Brown et al. 2018), and findings of the assessments provide consistency of priorities and scope for adaptation to moderate risk factors (Brown et al. 2018). Risk assessments provide information on what risks are expected in the future and what risks should be addressed first with response measures. Therefore, based on risk assessment results, decision-makers can set directions of adaptation policies and make strategies to reduce the negative consequences of the risks.

As risk assessment gets more attention, the importance of national-level risk assessment has also been emphasised, and many nations have conducted it as the first step of their national adaptation policy process (Brown 2015). For example, the UK established the Climate Change Act 2008 to provide legal foundations for risk assessments, and the UK government have reported their Climate Change Risk Assessments (CCRAs) in 2012 and 2017. The CCRAs provide the evidence base of climate risks that are expected to encounter and analyse the magnitude of the risks. Based on the assessment results, national-level adaptation measures for the next 5 years are developed (Brown et al. 2018). Germany established the Vulnerability Network, which consists of 16 federal departments and 9 departmental research institutes, to assess climate change vulnerabilities. They reported Germany's vulnerability to climate change (2015) and Climate change in Germany: trends, impacts, risks and adaptation (2017), which investigate climate signal, sensitivity and each sector's adaptive capacity. Based on a common understanding of vulnerability and continuous communications in the Vulnerability Network, Germany develops national-level response measures (Buth et al. 2015; Buth et al. 2017).

In 2014, the Republic of Korea (Korea) conducted a qualitative risk assessment (Korea Government 2015). In 2015, based on the risk assessment, the Korean government established the second National Climate Change Adaptation Policy (NCCAP). However, the risk assessment poses several limits. First, a lack of scientific evidence of risks is pointed out as a problem. As the risk assessment was conducted through experts' discussions and workshops, scientific evidence of risks was unlikely to sufficiently collected, and the results were deeply dependent on experts' opinions. Second, the results of the assessment may have limitations in developing adaptation measures. The list of priority risks provided to government departments lacked detailed information on how and to what extent risks should be addressed and responded to (Song et al. 2019). Lastly, there have been no official processes or systematic procedures for national-level climate change risk assessment in Korea, and relevant terms (risk, vulnerability) have been complexly used. It leads to different understandings of risk assessment, its results, range, and application according to sectors, departments, and actors. Making a common and clear understanding of relevant concepts and establishing an official systematic process of climate change risk assessment at the national level are required to use the risk assessment results and to address the risk effectively and systematically at the national level (i.e. Chapter 2 of UK CCRA evidence report 2017).

In this regard, this research aims to establish a nationallevel risk assessment process and methodologies, given the limited time/resource and insufficient climate change information. Also, the results of this risk assessment will inform to making the third NCCAP. From collecting scientific evidence to risk categorisation, this research set a whole process of risk assessment and detailed criteria for assessing climate change risks of Korea. Based on the process and criteria, we also identify national-level climate change risks of eight sectors: health, land, agriculture, water, forest, industry/energy, ecosystem, and ocean/fishery/coast. In addition, as the second NCCAP will be over at the end of 2020, these research results will play an essential role to develop and establish the third NCCAP of Korea.

\section{Establishing a systematic process of national-level risk assessment}

This research proposes a systematic climate change risk assessment for NCCAP of Korea using the current limited information and resources. Considering the limitation of the previous risk assessments, the proposed systematic risk assessment aims to collect scientific evidence of climate change risks, provide clear criteria of assessments, prioritising risks through systematic assessments, informing key points to making national adaptation policies, and apply consistent methodologies and criteria in national climate change risk assessments.

Thus, to meet the purpose, it sets four key considerations for the assessment through literature reviews, case studies, a review of the previous risk assessment of Korea and discussions with experts. 
- To make scientific evidence about climate change impacts (national-level) through reviewing reference (Buth et al. 2017; CCC 2017b; Brown et al. 2018).

- To utilise relationships between risks and between risk factors to identify major risks (Papathoma-Köhle et al. 2016; Buth et al. 2017; CCC 2017b).

- To correspond to the concept of "risk $=f$ (hazard, exposure, vulnerability)" by conducting assessments about adaptive capacity and adaptive measures (Preyssl et al. 1999; IPCC 2007, 2014; Tonmoy et al. 2018).

- To present urgency and category of each risk to increase the usability of the result of the risk assessment (CCC 2017b, 2021).

Although there are a variety of approaches and methods for national risk assessments, the choice of assessment approaches and methods needs to take into account the particular information needs and the purpose of each national risk assessment (EEA 2018). The major purposes of a climate change risk assessment of Korea are: (1) retaining scientific evidence of climate change risks of Korea, (2) identifying national-level climate change risks, and (3) prioritising identified climate change risks to provide information to national adaptation policy, rather than calculating related numbers concretely. Based on the considerations and the purposes, the risk assessment method consists of four steps: (1) collecting scientific evidence, (2) making lists of preliminary risks, (3) making lists of risks and prioritising, and (4) categorising the risks.

For consistent understandings, this assessment sets key terms. Following the definition in IPCC (2014), 'risk' results from the interaction of hazard $(h)$, exposure $(e)$, and vulnerability $(v)$; risk $=f(h, e, v)$. 'Climate impact' refers to the consequences of climate change, it is a concept that excludes vulnerability from risk, consisting of hazard $(h)$ and exposure $(e)$; climate impact $=f(h, e)$. 'Risk magnitude' refers to the sum of risk consequences and likelihood, which is measured in terms of the severity of its consequences $(s)$ and its probability of occurrence ( $p$ ) (Preyssl et al. 1999); risk magnitude $=f(s, p)$. 'Adaptive capacity' refers to "the combination of the strengths, attributes, and resources available to an individual, community, society, or organisation that can be used to prepare for and undertake actions to reduce adverse impacts, moderate harm, or exploit beneficial opportunities" (IPCC 2014, p. 1758). Thus, this assessment considers that the adaptive capacity can represent the vulnerability $(v)$ in the function of risk, as the vulnerability consists of sensitivity $(s)$ and adaptative capacity (ac) (IPCC 2007, 2014). To measure adaptive capacity, this assessment includes institutional capacity $(i)$, actor capacity $(a)$, infrastructure capacity $(f)$, technological capacity $(t)$; adaptative capacity $=f(i, a, f, t)$.

\section{Collecting scientific evidence}

Scientific evidence plays an important role in risk assessments, providing scientific grounds for making adaptative actions and helping to devise proper adaptation actions with various evidence and approaches. Thus, this risk assessment introduces a systematic literature review (SLR) to collect scientific evidence. SLR is a literature review methodology following a clearly defined protocol or plan where the criteria are set before the review is conducted (Dewey and Drahota 2016). It makes it possible to collect data systematically and comprehensively, as well as reduces subjective errors or bias of selecting literature to review (Petticrew and Roberts 2006). As a summary and assessment of the status of knowledge on a given topic or research question, SLRs have been increasingly used in the climate change field (Berrang-Ford et al. 2011; Ford and Berrang-Ford 2011; Spires et al. 2014). Thus, this risk assessment conducts an SLR following the seven stages of SLRs (see Petticrew and Roberts 2006, p.27) to enhance scientific evidence of climate change impacts on Korea. It sets three research questions for an SLR: (1) What are climate change risks of each sector in Korea (including national and local levels)? (2) What are the research results on the risk's factors (hazard, exposure, vulnerability) and impacts? (3) What are Korea national climate change risks drawn through analysing the risk factors and impacts? To make a clear and objective data range focusing on climate change impacts on Korea, this risk assessment chooses two web databases (KISS (http:// kiss.kstudy.com) and DBpia (https://www.dbpia.co.kr)) that are the biggest and most frequently used in Korea. In order to collect objectively verified data, at first, it searches only peer-reviewed articles in the databases. Both Korean ([ 기 후 변화]) and English ([climate change]) terms were used to search. It is supposed that studies on climate change in Korea published before 2014 were reviewed and involved in Korean Climate Change Assessment Report (MoE and NIER 2014); thus, we focused on studies published between 2014 and 2019 in this risk assessment searches. In May 2019, total 20,518 articles are retained (KISS: 1,952; DBpia: 18,566). The criteria for inclusion and exclusion are summarised in Table 1. Based on the criteria, a total of 565 articles were identified and analysed (Table 2).

\section{Making lists of preliminary risks}

Preliminary risks refer to potential risks that can be drawn from related literature and data review, without adaptive capacity assessments. Acknowledging that academic articles in the SLR do not include every aspect of climate change risks of Korea, 'the climate impact database' is additionally reviewed to supplement the SLR results and make broader lists of preliminary risks. The climate impact database 
Table 1 Criteria for inclusion and exclusion

\begin{tabular}{|c|c|c|}
\hline Criteria & Inclusion & Exclusion \\
\hline Date of publication & Articles published between Jan 2014-May 2019 & Articles published prior to Jan 2014 \\
\hline Main theme of publication & $\begin{array}{l}\text { Articles focusing on analysing or projecting climate } \\
\text { change impacts on Korea (past/present/future) } \\
\text { Articles involving contents about climate change, } \\
\text { climate change scenario, climate change impacts, RCP, } \\
\text { GCM, etc. }\end{array}$ & $\begin{array}{l}\text { Articles not involving contents about climate change, } \\
\text { climate change scenario, climate change impact, RCP, } \\
\text { GCM, etc., which are not related to climate change } \\
\text { risks }\end{array}$ \\
\hline Research range & Articles focusing on Korea (national and local areas) & Articles focusing on other countries and their local areas \\
\hline Availability of article & Articles that are available in KISS and Dbpia & Articles that are not available in KISS and DBpia \\
\hline Type of article & Only peer-reviewed and published article & $\begin{array}{l}\text { Grey literature such as conference proceedings or reports } \\
\text { for institutes }\end{array}$ \\
\hline Language of publication & Articles published in Korean or English & $\begin{array}{l}\text { Articles published in languages other than Korean or } \\
\text { English }\end{array}$ \\
\hline
\end{tabular}

Table 2 Analysis criteria

\begin{tabular}{|c|c|}
\hline Criteria & Description \\
\hline Sector & $\begin{array}{l}\text { Research sector (Health, Land, Coast, Agriculture, Water, Energy, Forest, Industry, Ecosystem, Ocean, Fisheries, } \\
\text { etc.) }\end{array}$ \\
\hline Spatial range & Research spatial range (national, provincial, local) \\
\hline Data time scale & Time scale of data that used in the research \\
\hline Research time scale & Time scale of the research subject (past, present, future) \\
\hline Risk factors (IPCC 2014) & $\begin{array}{l}\text { Hazard-The potential occurrence of a natural or human-induced physical event or trend or physical impact that may } \\
\text { cause loss of life, injury, or other health impacts, as well as damage and loss to property, infrastructure, liveli- } \\
\text { hoods, service provision, ecosystems, and environmental resources. In this report, the term hazard usually refers to } \\
\text { climate-related physical events or trends or their physical impacts } \\
\text { Exposure-The presence of people, livelihoods, species or ecosystems, environmental functions, services, and } \\
\text { resources, infrastructure, or economic, social, or cultural assets in places and settings that could be adversely } \\
\text { affected } \\
\text { Vulnerability-The propensity or predisposition to be adversely affected. Vulnerability encompasses a variety of } \\
\text { concepts and elements including sensitivity or susceptibility to harm and lack of capacity to cope and adapt. See } \\
\text { also Contextual vulnerability and Outcome vulnerability }\end{array}$ \\
\hline Research result & Research result summary \\
\hline Risk description & Risk description with risk factors in the research \\
\hline
\end{tabular}

was used to build causation maps to supplement the SLR results. The climate impact database was established (Sin et al. 2017), which consists of risk factors (hazard, exposure, impact, and risk). It provides information about climate impacts on the real-life of each sector. Based on the results of the SLR and the climate impact database review, lists of preliminary sectoral climate change risks are drawn. The preliminary risks are classified into eight sectors: health, land, agriculture, water, forest, industry/energy, ecosystem, and ocean/fishery/coast.

\section{Making lists of risks and prioritising}

In this step, every progress is conducted by sectoral expert groups; seven to ten experts from academia, research institutes, public organisations, etc. participated in each sectoral expert group. The preliminary risks, first, are reviewed and revised by sectoral expert groups. In this step, new risks that sectoral experts consider important risks but are not included in the lists of preliminary risks can be added. Also, risks that are not significant enough to be considered are eliminated through expert discussion in this step. Given that research articles cannot deal with all climate change risks and authors have bias to choose research topics, adding and deleting risks through sectoral expert discussions are essentially required. Then, the sectoral expert groups select each sector's climate change risks. The selected risks are prioritised by assessing risk magnitude and adaptive capacity. Following the definitions of key terms and concepts, the severity of the risk consequences (s) and the probability of the risk occurrence $(p)$ are used to assess the risk magnitude. These are assessed with a three-point scale from low to high (Table 3 ). The adaptive capacity assessment consists of four sub-assessments, which assess with a five-point scale 
Table 3 Criteria for assessing risk scale and probability (three-point scale)

\begin{tabular}{lll}
\hline & Scale & Description \\
\hline $\begin{array}{l}\text { The severity of the risk } \\
\text { consequences }\end{array}$ & $\begin{array}{l}\text { High } \\
\text { Medium } \\
\text { Low }\end{array}$ & $\begin{array}{l}\text { Large scale damage that is repeated every year (national-level, over 10 billion won) } \\
\text { Medium-scale damage that is repeated every year (national or local level, over 1 billion won) } \\
\text { Small scale damage that is repeated every year (the damage amount is small compared to the } \\
\text { number of damages) }\end{array}$ \\
$\begin{array}{ll}\text { The probability of the risk } \\
\text { occurrence }\end{array}$ & $\begin{array}{l}\text { High } \\
\text { Medium }\end{array}$ & $\begin{array}{l}\text { Once in 2 or 3 years } \\
\text { Low }\end{array}$ \\
& Once in over 5 years
\end{tabular}

Table 4 Criteria for assessing adaptive capacity (five-point scale)

\begin{tabular}{ll}
\hline Assessment & Description \\
\hline Institutional capacity assessment & $\begin{array}{l}\text { Do you think the national legislations and institutions for this risk has been properly developed? } \\
\text { Do you think there are enough national countermeasures (policy programmes) to address this risk? }\end{array}$ \\
Actor capability assessment & How much do you think the actors' (related organisations and main respondents) adaptative capacity is? \\
Infrastructure capacity assessment & Do you think the social infrastructures for this risk are working sufficiently and effectively? \\
Technical capability assessment & What level do you think the basic research (projection, information, technology development, etc.) is?
\end{tabular}

from low to high: institutional capacity ( $i)$, actor capacity $(a)$, infrastructure capacity $(f)$, technological capacity $(t)$ (Table 4). Each expert assesses each risk's magnitude and adaptative capacity, the results are calculated by summing and averaging in each sector, and every risk of each sector is presented in a quadrant sheet consisting of the risk magnitude and adaptive capacity dimensions. By mapping assessed risks on the quadrant sheet, it makes it possible to see the urgency of the risk. Based on the results of each sector's quadrant sheet, the experts prioritised climate change risks.

\section{Categorising the risks}

To use the results of the climate change risk assessment in national adaptation policy processes, it is necessary to identify how the risks have been dealt with. Thus, this assessment categorises identified risks into four categories based on the institutional capacity assessment and the technological capability assessment: 'existing', 'new', 'fundamental research', and 'new and fundamental research'. 'Existing' means that the risk can be dealt with existing measures, 'new' refers to the need to add new measure in the next adaptation policy to address the risk and there is enough fundamental knowledge about the risk, 'fundamental research' refers to the current institutions have measures to address the risk but more basic research and understandings are required to address it more effectively and efficiently, and 'new and fundamental research' means that the identified risk was not dealt with by previous adaptation measures, as well as it needs fundamental research to understand and reduce the risk.

The four steps of national-level climate change risk assessment described above are summarised in Fig. 1.

\section{Result: identifying national-level climate change risk of Korea}

\section{Preliminary climate change risks of Korea}

This risk assessment drew sectoral preliminary climate change risk lists through analysing retained 565 articles of the SLR and the climate impact database from Sin et al. (2017). In eight sectors, 204 climate impacts $^{1}$ and potential risks (without adaptive capacity assessments) which have scientific evidence were drawn: 10 for health, 23 for land, 32 for agriculture, 24 for water, 13 for forest, 52 for industry/ energy, 31 for ecosystem, and 19 for ocean/fishery/coast. For example, the preliminary risks of the health sector are presented in Table 5.

\section{Climate change risks in Korea}

Sectoral expert groups selected 95 climate change risks of Korea through reviewing and revising the preliminary risks.

\footnotetext{
1 As it is defined in "Establishing a systematic process of nationallevel risk assessment", climate impact consists of hazard $(h)$ and exposure $(e)$, without vulnerability $(v)$.
} 
Step

Description

Reference

Method

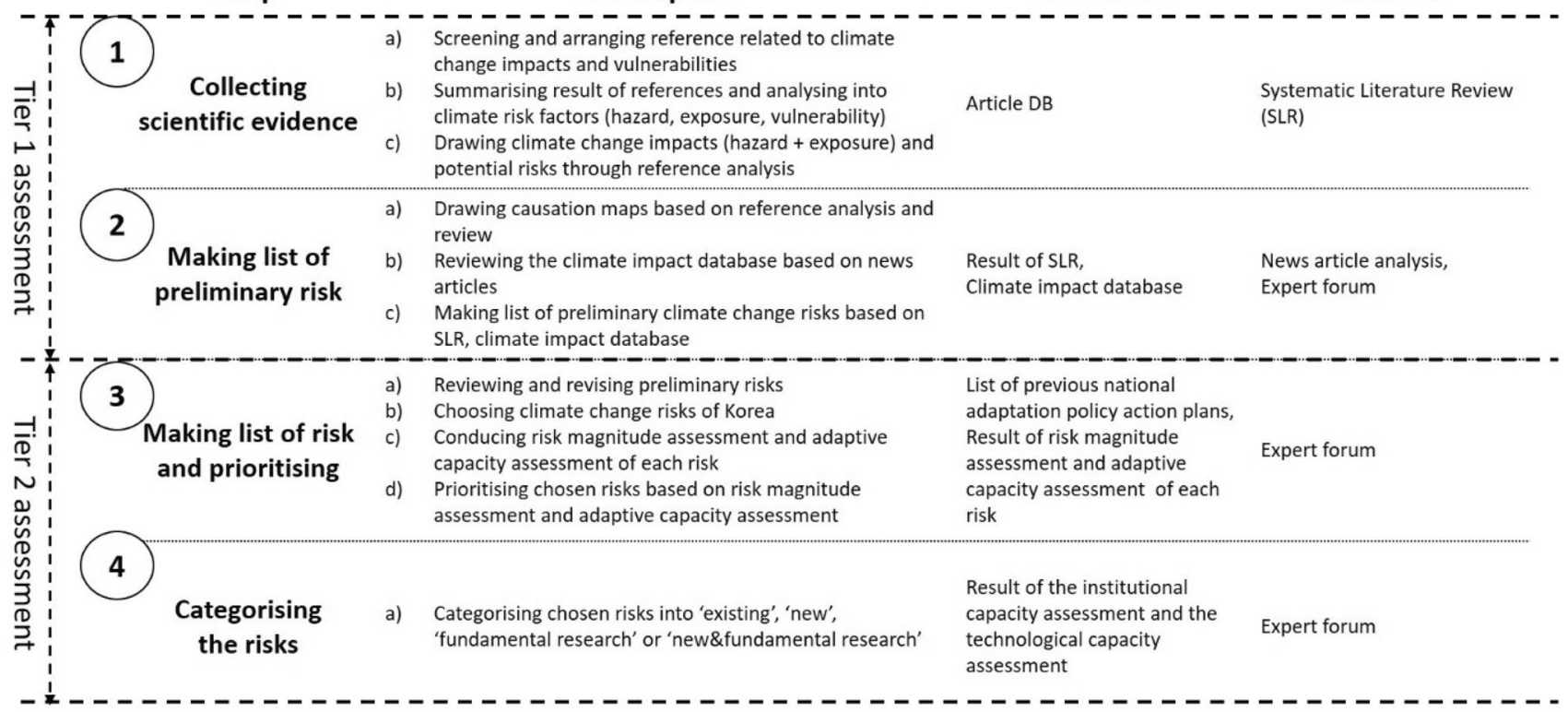

Fig. 1 Process of risk assessment

Table 5 Preliminary risks of health sector

\begin{tabular}{|c|c|c|c|c|}
\hline No. & Hazard & Exposure & Impact (hazard and exposure) & Potential risk \\
\hline 1 & $\begin{array}{l}\text { Temperature increase, precipitation } \\
\text { reduction }\end{array}$ & Patients & Allergic disease increase & $\begin{array}{l}\text { Allergic disease increase due to tempera- } \\
\text { ture increase }\end{array}$ \\
\hline 2 & Temperature increase, high temperature & Patients & Malaria disease increase & $\begin{array}{l}\text { Malaria disease increase due to tempera- } \\
\text { ture increase }\end{array}$ \\
\hline 3 & Temperature increase, high temperature & Patients & Food poisoning increase & $\begin{array}{l}\text { Food poisoning increase due to tempera- } \\
\text { ture increase }\end{array}$ \\
\hline 4 & Temperature increase, humidity increase & Patients & Bacterial pathogen increase & $\begin{array}{l}\text { Bacterial pathogen increase due to tem- } \\
\text { perature and humidity increase }\end{array}$ \\
\hline 5 & Heat wave & The aged & $\begin{array}{l}\text { Respirator and cardiovascular sys- } \\
\text { tem patients increase, Medical cost } \\
\text { increase }\end{array}$ & $\begin{array}{l}\text { Respirator and cardiovascular system } \\
\text { patients increase due to heat wave }\end{array}$ \\
\hline 6 & Heat wave & Patients & Fatality increase & Fatality increase due to heat wave \\
\hline 7 & $\begin{array}{l}\text { Ozone concentration increase, tempera- } \\
\text { ture increase, precipitation increase }\end{array}$ & Patients & $\begin{array}{l}\text { Early fatality increase due to air pollu- } \\
\text { tion }\end{array}$ & $\begin{array}{l}\text { Early fatality increase due to air pollution } \\
\text { caused by temperature, ozone concen- } \\
\text { tration increase }\end{array}$ \\
\hline 8 & Temperature increase, high temperature & Patients & Renal colic increase & $\begin{array}{l}\text { Renal colic increase due to temperature } \\
\text { increase }\end{array}$ \\
\hline 9 & $\begin{array}{l}\text { Temperature increase, } \mathrm{CO}_{2} \text { concentra- } \\
\text { tion increase }\end{array}$ & Patients & Asthmatic patient increase & $\begin{array}{l}\text { Asthmatic patient increase due to tem- } \\
\text { perature and } \mathrm{CO}_{2} \text { concentration increase }\end{array}$ \\
\hline 10 & Precipitation reduction & Human & $\begin{array}{l}\text { Respiratory disease and skin disease } \\
\text { increase }\end{array}$ & $\begin{array}{l}\text { Respiratory disease and skin disease } \\
\text { increase due to dry air }\end{array}$ \\
\hline
\end{tabular}

In this process, sectoral experts updated the risks by adding new important risks, removing or merging. For example, in the health sector, 'water-borne diseases increase due to temperature increase' and 'mediator diseases increase due to temperature increase' were added, and subsequently, 12 climate change risks for the health sector were selected. The number of risks in the industry/energy sector also decreased from 52 to 13 by removing inconsiderable risks or merging similar risks.

The assessment results of risk magnitude and adaptation capability of the 95 risks were plotted in each sectoral quadrant sheet. In Fig. 2, the upper-right quadrant refers to a 


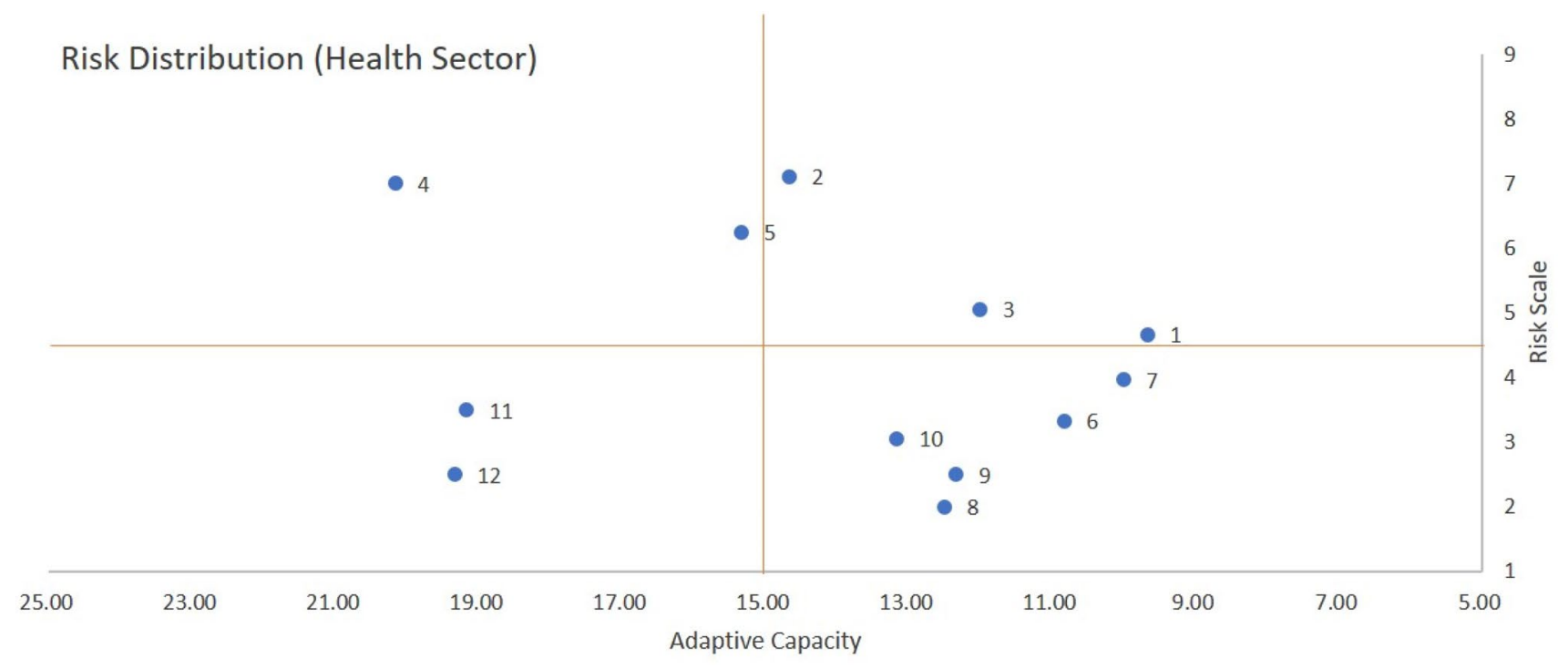

Fig. 2 Risk distribution (health)

risk that has high risk severity and probability but low adaptive capacity, while the upper-left quadrant refers to a risk that has high risk severity and probability and high adaptive capacity. In contrast, the lower-right quadrant shows a risk that has low risk severity and probability and low adaptive capacity, and the lower-left quadrant presents a risk that has low risk severity and probability but high adaptive capacity.

Lastly, 93 risks were selected as climate change risks of Korea through mediations between sectors (12 for health, 12 for land, 14 for agriculture, 10 for water, 12 for forest, 11 for ecosystem, 12 for industry/energy, and 10 for ocean/ fishery/coast). There were some similar risks between sectors, and two risks from water and industry/energy sectors were removed by comparing all selected risks.

In the expert forum, the selected risks were prioritised, based on the results of the assessments of the risk magnitude and adaptive capacity. Most high priorities in the risks commonly have high risk magnitude but low adaptive capacity, although a few risks were exceptionally added to the high priority through expert discussions. The priorities of the 93 risks are shown in Appendix, and high ranked risks have a high priority.

\section{Risk categorisation}

Based on the analysis of institutional capacity assessment and technological capability assessment, this risk assessment classified the identified 93 risks into the four categories (see "Categorising the risks").

In this categorisation, it showed very different results according to each sector (Table 6). For example, agriculture and industry/energy sectors have a high proportion of risks in the existing category. This suggests that most of the climate change risks in these sectors were already covered by existing measures. Subsequently, less new measures or additional research were added. In contrast, ecosystem and ocean/fishery/coast sectors had one or no risk in the existing category, and most risks were in the new and fundamental research category. It means that existing measures in these sectors need to be reconsidered and redesigned to address their identified risks.

\section{Discussion and conclusion}

As the importance of managing climate change risks has been widely acknowledged, risk assessment has been to the fore as the first step of risk management (PapathomaKöhle et al. 2016; Adger et al. 2018; Dawson et al. 2018;

Table 6 Risk categorisation

\begin{tabular}{lllll}
\hline Sector & Existing & New & $\begin{array}{l}\text { Fundamen- } \\
\text { tal research }\end{array}$ & $\begin{array}{l}\text { New and } \\
\text { fundamental } \\
\text { research }\end{array}$ \\
\hline Health & 3 & 3 & 0 & 6 \\
Land & 1 & 6 & 0 & 5 \\
Agriculture & 9 & 3 & 1 & 1 \\
Water & 1 & 5 & 1 & 3 \\
Forest & 2 & 6 & 0 & 4 \\
Ecosystem & 1 & 0 & 1 & 9 \\
Industry/energy & 8 & 1 & 0 & 3 \\
Ocean/fishery/coast & 0 & 0 & 0 & 10 \\
\hline
\end{tabular}


EEA 2018). In this respect, Korean government conducted a national-level climate change risk assessment in 2014 to establish the second NCCAP, but there were several limits that hinder from understanding the concept of climate change risks to the use of the risk assessment results in adaptation measures. Thus, this research aimed to establish a systematic national-level risk assessment process and methodology given the limited time/resources and insufficient climate change information. Also, through identifying risks, it purposed to provide essential insights into making the third NCCAP.

The climate change risk assessment methods in other countries require a large amount of time and resources (human and financial). For example, the UK's CCRA takes at least 2 years to collect scientific evidence (in the first year) and to assess the risks (in the second year), and it also includes a number of policy stakeholders and sectoral experts. Also, significant costs are required in this process (CCC 2021). These risk assessment methods are not proper for countries that don't have sufficient resources, expertise or that need to immediately conduct a risks assessment for their national adaptation policy. Thus, in this research, a four-step climate change risk assessment is proposed that is considering the current limited time/resources and insufficient climate change information: collecting scientific evidence, making lists of preliminary risks, making lists of risks and prioritising, and categorising the risks. Based on a Korean case, the proposed risk assessment process took only 6-8 months to draw meaningful assessment results.

This risk assessment process retained scientific evidence and data about the climate change risks of Korea through the first two steps. Through an SLR and the climate impact database of Korea, this research drew 204 climate impacts on Korea and collects related scientific evidence. We found that industry/energy, agriculture, water, and ecosystem sectors relatively had more research evidence than other sectors. Although we collected plenty of scientific evidence of risks, there are still gaps. The gaps in data and the integration of quantitative and qualitative information are the common challenges of national-level risk assessments (EEA 2018). Thus, it is important that the risk assessment process has room for adding scientific evidence and data of risks in the next steps through additional analysis or expert discussions. However, it is emphasised that these early steps of the proposed risk assessment in this study can retain baseline scientific evidence and data of climate change risks for Korea, which were not made in the previous assessments.

The process of assessing the magnitude and adaptive capacity of risks revealed that the risk assessment process could involve three components of risks: hazard, exposure, and vulnerability. This research suggested expert surveys and expert group discussions to identify climate change risks for Korea and to prioritise identified risks, not to calculate the magnitude of risks and vulnerability with statistical models. Expert survey and expert group discussion methods were commonly used to assign weights of indicators to identify high-vulnerabilities and to classify grades in other risk assessments (Feng and Chao 2020). Based on the criteria of risk severity and risk probability, sectoral experts assessed the 95 selected climate change risks from the preliminary risk lists. In addition, to assess vulnerability, this research suggested assessing an adaptive capacity for each selected risk in four aspects: institutional capacity, actor capability, infrastructure capacity, and technological capability. Although the assessments still relied on experts' subjective opinions, this assessment provided clear criteria and factors for assessing compared to the previous risk assessment.

The 93 risks were chosen as the final national climate change risks for Korea by displaying the risks on sectoral quadrant sheets consisting of risk magnitude and adaptive capacity dimensions. Also, the priority of each risk in each sector was given in this step. Most high priorities in risks have high risk magnitude but low adaptive capacity (in the upper-right quadrant).

This research provided insights for directions of national adaptation policy of each sector by categorising the 93 risks into four categories (existing, new, fundamental research, and new and fundamental research). The results showed that only one-third of national climate change risks of Korea can be dealt with existing measures or policies. Also, there were differences between sectors. In particular, agriculture and industry/energy sectors can deal with most sectoral risks with existing measures, whereas ecosystem and ocean/fishery/coast sectors cannot deal with any risks with existing adaptation measures. These results indicate that sectors like agriculture and industry/energy need to focus mainly on maintaining the current adaptation measures in the next NCCAP. Ecosystem and ocean/fishery/coast sectors have to check the problems or directions of the current adaptation measures first and then develop their measures based on identified risks for the next NCCAP. In addition, the results revealed that Korea still does not have enough fundamental research to address climate changes risks and need to invest in more to each sector's fundamental research, although the government has implemented the adaptation policy for about past 10 years. More than one-third of the national climate change risks for Korea requires new measures and fundamental research. The risks of sectors seem to need immediate actions to address them. However, policy-makers should pay attention to and invest in fundamental research for the risks with long-term views. Moreover, for the risks with a lack of research but requiring quick responses, it is necessary to prepare policies through a discussion process so that basic research and direct action can be carried out at the same time. 
It is acknowledged that there were several limitations in this risk assessment method. First, this assessment had a limitation in dealing with cross-cutting risks, as we focused on sectoral risks separately. Secondly, this risk assessment did not involve a spatial concept; thereby, it did not involve how the national risk assessment link with and use sub-nationallevel climate change risk assessments. Thus, there is a need for research on risk assessments that include horizontal and vertical cross-cutting risk issues. Third, the SLR in collecting scientific evidence step reviewed only domestic journals to set subjective and clear inclusion criteria. If one can set subjective criteria that can include international journals, it would be helpful to collecting a wider range of scientific evidence related to climate change risks. In addition, because this risk assessment focused on establishing a systematic methodology that can be efficiently conducted with limited resources and time, it did not address every specific factor related to a climate change risk separately. For example, to assess a vulnerability, the proposed risk assessment focuses on adaptive capacity, excluding a sensitivity (such as elderly population density), to make the assessment more efficient and easier based on only related policy data, excluding demographic data. To address this limitation, it is required to develop an assessment method that can combine sensitivity with demographic data and adaptive capacity with related policy data.

With the Paris Agreement and Katowice Climate Package, it became a clear mandate for all parties to undertake adaptation progress and report their efforts to the international society (Berrang-Ford et al. 2019), and a climate change risk assessment is being essentially required for their national adaptation policy. In this context, this study will be of great help to countries where a climate change risk assessment needs to be conducted immediately but systematically. In addition, this assessment process can be used not only at the national level, but also at local or individual organisational level risk assessments.

\section{Appendix}

Prioritised climate change risks of Korea (93 risks)

\begin{tabular}{|c|c|c|c|c|c|c|c|c|}
\hline \multirow[t]{2}{*}{ No. } & Health & Land & Agriculture & Water & Forest & Industry/energy & Ecosystem & $\begin{array}{l}\text { Ocean/fishery/ } \\
\text { coast }\end{array}$ \\
\hline & 12 & 12 & 14 & 10 & 12 & 12 & 11 & 10 \\
\hline 1 & $\begin{array}{l}\text { Mental health } \\
\text { diseases } \\
\text { increase due } \\
\text { to heat wave }\end{array}$ & $\begin{array}{l}\text { Interruption } \\
\text { and accident } \\
\text { of land trans- } \\
\text { portation } \\
\text { increase due } \\
\text { to heavy rain } \\
\text { and heavy } \\
\text { snow }\end{array}$ & $\begin{array}{l}\text { Livestock dis- } \\
\text { ease increase } \\
\text { due to cold } \\
\text { wave and heat } \\
\text { wave }\end{array}$ & $\begin{array}{l}\text { Intensification } \\
\text { of drying } \\
\text { stream due } \\
\text { to drought }\end{array}$ & $\begin{array}{l}\text { Unstable } \\
\text { production } \\
\text { of forest } \\
\text { products due } \\
\text { to abnormal } \\
\text { climate }\end{array}$ & $\begin{array}{l}\text { Manufacturing } \\
\text { productivity } \\
\text { decrease due } \\
\text { to heat wave, } \\
\text { cold wave, } \\
\text { and heavy rain }\end{array}$ & $\begin{array}{l}\text { Plant change } \\
\text { (species, } \\
\text { colony, plant } \\
\text { season, dis- } \\
\text { tribution) due } \\
\text { to increase of } \\
\text { temperature } \\
\text { and precipi- } \\
\text { tation }\end{array}$ & $\begin{array}{l}\text { Risk of flood- } \\
\text { ing in coastal } \\
\text { areas increase } \\
\text { due to heavy } \\
\text { rain, tidal } \\
\text { wave, ocean } \\
\text { wave, and sea } \\
\text { level rise }\end{array}$ \\
\hline 2 & $\begin{array}{l}\text { Cardiovascu- } \\
\text { lar diseases } \\
\text { increase due } \\
\text { to air pollu- } \\
\text { tion }\end{array}$ & $\begin{array}{l}\text { Damage to } \\
\text { electricity/ } \\
\text { communica- } \\
\text { tion facilities } \\
\text { due to abnor- } \\
\text { mal weather } \\
\text { events }\end{array}$ & $\begin{array}{l}\text { Livestock } \\
\text { productivity } \\
\text { decrease due } \\
\text { to heat wave, } \\
\text { temperature } \\
\text { increase, and } \\
\text { humidity } \\
\text { increase }\end{array}$ & $\begin{array}{l}\text { Stream and } \\
\text { lake water } \\
\text { quality } \\
\text { deteriora- } \\
\text { tion due to } \\
\text { temperature } \\
\text { increase and } \\
\text { drought }\end{array}$ & $\begin{array}{l}\text { Damage from } \\
\text { forest pests } \\
\text { increase due } \\
\text { to heat wave } \\
\text { and heavy } \\
\text { rain }\end{array}$ & $\begin{array}{l}\text { Damage of pro- } \\
\text { duction facili- } \\
\text { ties increase } \\
\text { due to strong } \\
\text { wind }\end{array}$ & $\begin{array}{l}\text { Soil microbial } \\
\text { change due } \\
\text { to tempera- } \\
\text { ture increase, } \\
\text { precipitation } \\
\text { fluctuation } \\
\text { and drought }\end{array}$ & $\begin{array}{l}\text { Erosion of } \\
\text { white sand } \\
\text { beaches, sand } \\
\text { dunes, coasts, } \\
\text { mudflats, } \\
\text { and forests } \\
\text { increase due } \\
\text { to ocean } \\
\text { wave and sea } \\
\text { level rise }\end{array}$ \\
\hline 3 & $\begin{array}{l}\text { Cardiovascu- } \\
\text { lar diseases } \\
\text { increase due } \\
\text { to tempera- } \\
\text { ture increase }\end{array}$ & $\begin{array}{l}\text { Drainage } \\
\text { facility } \\
\text { performance } \\
\text { decrease } \\
\text { due to rain } \\
\text { pattern fluc- } \\
\text { tuation }\end{array}$ & $\begin{array}{l}\text { Damage } \\
\text { to facili- } \\
\text { ties (barn, } \\
\text { greenhouse) } \\
\text { increase due } \\
\text { to heavy snow } \\
\text { and strong } \\
\text { wind }\end{array}$ & $\begin{array}{l}\text { Inflow of } \\
\text { pollutants to } \\
\text { steam and } \\
\text { lake increase } \\
\text { due to heavy } \\
\text { rain }\end{array}$ & $\begin{array}{l}\text { Forest produc- } \\
\text { tion growth } \\
\text { reduction } \\
\text { and quality } \\
\text { deteriora- } \\
\text { tion due to } \\
\text { drought and } \\
\text { heavy rain }\end{array}$ & $\begin{array}{l}\text { Damage to the } \\
\text { construc- } \\
\text { tion industry } \\
\text { increase due } \\
\text { to extreme } \\
\text { weather } \\
\text { events }\end{array}$ & $\begin{array}{l}\text { Changes in } \\
\text { subalpine } \\
\text { areas (spe- } \\
\text { cies, growth, } \\
\text { distribu- } \\
\text { tion) due to } \\
\text { temperature } \\
\text { increase and } \\
\text { precipitation } \\
\text { fluctuation }\end{array}$ & $\begin{array}{l}\text { Damage to } \\
\text { coastal facili- } \\
\text { ties increase } \\
\text { due to tidal } \\
\text { wave, strong } \\
\text { wind, ocean } \\
\text { wave, and sea } \\
\text { level rise }\end{array}$ \\
\hline
\end{tabular}




\begin{tabular}{|c|c|c|c|c|c|c|c|c|}
\hline \multirow[t]{2}{*}{ No. } & Health & Land & Agriculture & Water & Forest & Industry/energy & Ecosystem & $\begin{array}{l}\text { Ocean/fishery/ } \\
\text { coast }\end{array}$ \\
\hline & 12 & 12 & 14 & 10 & 12 & 12 & 11 & 10 \\
\hline 4 & $\begin{array}{l}\text { Heat diseases } \\
\text { increase due } \\
\text { to heat wave }\end{array}$ & $\begin{array}{l}\text { Damage to old } \\
\text { buildings } \\
\text { due to heavy } \\
\text { snow and } \\
\text { strong wind }\end{array}$ & $\begin{array}{l}\text { Flooding of } \\
\text { agricultural } \\
\text { land, loss of } \\
\text { soil, and agri- } \\
\text { cultural water } \\
\text { pollution due } \\
\text { to heavy rain }\end{array}$ & $\begin{array}{l}\text { Flood damage } \\
\text { to streams } \\
\text { and water- } \\
\text { sheds due to } \\
\text { heavy rain }\end{array}$ & $\begin{array}{l}\text { Forest distur- } \\
\text { bance spe- } \\
\text { cies and its } \\
\text { population } \\
\text { increase due } \\
\text { to abnormal } \\
\text { climate }\end{array}$ & $\begin{array}{l}\text { Damage to the } \\
\text { tourism indus- } \\
\text { try increase } \\
\text { and tourists } \\
\text { decrease due } \\
\text { to temperature } \\
\text { increase, heat } \\
\text { wave, heavy } \\
\text { rain, drought }\end{array}$ & $\begin{array}{l}\text { Exotic species } \\
\text { (animals, } \\
\text { plants) } \\
\text { increase due } \\
\text { to climate } \\
\text { change }\end{array}$ & $\begin{array}{l}\text { Ecological } \\
\text { environmen- } \\
\text { tal change in } \\
\text { coastal and } \\
\text { river estuary } \\
\text { areas due to } \\
\text { changes in } \\
\text { rainfall pat- } \\
\text { tern }\end{array}$ \\
\hline 5 & $\begin{array}{l}\text { Respiratory/ } \\
\text { allergic } \\
\text { diseases } \\
\text { increase due } \\
\text { to air pollu- } \\
\text { tion }\end{array}$ & $\begin{array}{l}\text { Urban flood } \\
\text { damage } \\
\text { increase due } \\
\text { to heavy rain }\end{array}$ & $\begin{array}{l}\text { Changes in crop } \\
\text { productivity } \\
\text { due to extreme } \\
\text { weather events }\end{array}$ & $\begin{array}{l}\text { Water sup- } \\
\text { ply (life, } \\
\text { industry, } \\
\text { agriculture, } \\
\text { river main- } \\
\text { tenance) } \\
\text { performance } \\
\text { decrease due } \\
\text { to drought }\end{array}$ & $\begin{array}{l}\text { Forest habitats } \\
\text { changes due } \\
\text { to tempera- } \\
\text { ture increase }\end{array}$ & $\begin{array}{l}\text { Damage to sun- } \\
\text { light genera- } \\
\text { tion facilities } \\
\text { increase due } \\
\text { to strong wind } \\
\text { and typhoon }\end{array}$ & $\begin{array}{l}\text { Vertebrates } \\
\text { population } \\
\text { and their } \\
\text { habitats } \\
\text { decrease due } \\
\text { to tem- } \\
\text { perature and } \\
\text { precipitation } \\
\text { increase }\end{array}$ & $\begin{array}{l}\text { Damage to } \\
\text { the marine } \\
\text { ecosystem } \\
\text { due to ocean } \\
\text { acidification }\end{array}$ \\
\hline 6 & $\begin{array}{l}\text { Kidney } \\
\text { disease } \\
\text { increase due } \\
\text { to heat wave }\end{array}$ & $\begin{array}{l}\text { Risk of low- } \\
\text { level flood- } \\
\text { ing increase } \\
\text { due to heavy } \\
\text { rain }\end{array}$ & $\begin{array}{l}\text { Damage of crop } \\
\text { pests increase } \\
\text { due to tem- } \\
\text { perature and } \\
\text { precipitation } \\
\text { increase }\end{array}$ & $\begin{array}{l}\text { Vulnerability } \\
\text { of dam/ } \\
\text { reservoir } \\
\text { management } \\
\text { increase due } \\
\text { to rainfall } \\
\text { fluctuation } \\
\text { increase }\end{array}$ & $\begin{array}{l}\text { Carbon uptake } \\
\text { in forests } \\
\text { reduc- } \\
\text { tion due to } \\
\text { drought and } \\
\text { temperature } \\
\text { increase }\end{array}$ & $\begin{array}{l}\text { Use of heating } \\
\text { and cool- } \\
\text { ing energy } \\
\text { increase and } \\
\text { related cost } \\
\text { increase due } \\
\text { to cold wave } \\
\text { and heat wave }\end{array}$ & $\begin{array}{l}\text { Invertebrates } \\
\text { population } \\
\text { and habitats } \\
\text { decrease due } \\
\text { to tem- } \\
\text { perature and } \\
\text { precipitation } \\
\text { increase }\end{array}$ & $\begin{array}{l}\text { Changes in } \\
\text { intertidal and } \\
\text { estuary area } \\
\text { ecosystem } \\
\text { due to sea } \\
\text { level rise }\end{array}$ \\
\hline 7 & $\begin{array}{l}\text { Mental health } \\
\text { disease } \\
\text { increase due } \\
\text { to air pollu- } \\
\text { tion }\end{array}$ & $\begin{array}{l}\text { Risk of col- } \\
\text { lapse of } \\
\text { slopes in } \\
\text { residential } \\
\text { areas due to } \\
\text { heavy rain }\end{array}$ & $\begin{array}{l}\text { Crop productiv- } \\
\text { ity decrease } \\
\text { due to } \\
\text { temperature } \\
\text { increase }\end{array}$ & $\begin{array}{l}\text { Infrastructure } \\
\text { stability } \\
\text { of dams } \\
\text { and rivers } \\
\text { decrease due } \\
\text { to heavy rain }\end{array}$ & $\begin{array}{l}\text { Growth and } \\
\text { distribution } \\
\text { of subalpine } \\
\text { vegetation, } \\
\text { conifer- } \\
\text { ous forests, } \\
\text { northern } \\
\text { plants } \\
\text { decrease due } \\
\text { to tempera- } \\
\text { ture increase }\end{array}$ & $\begin{array}{l}\text { Electricity } \\
\text { demand } \\
\text { increase and } \\
\text { risk of black- } \\
\text { out increase } \\
\text { due to cold } \\
\text { wave and heat } \\
\text { wave }\end{array}$ & $\begin{array}{l}\text { Endangered } \\
\text { species } \\
\text { and rare/ } \\
\text { protected } \\
\text { species } \\
\text { reduction due } \\
\text { to climate } \\
\text { change }\end{array}$ & $\begin{array}{l}\text { Ocean foreign/ } \\
\text { pirate } \\
\text { creature } \\
\text { emergence } \\
\text { and related } \\
\text { diseases } \\
\text { increase due } \\
\text { to seawater } \\
\text { temperature } \\
\text { increase }\end{array}$ \\
\hline 8 & $\begin{array}{l}\text { Respiratory } \\
\text { and allergic } \\
\text { diseases } \\
\text { increase due } \\
\text { to tempera- } \\
\text { ture increase }\end{array}$ & $\begin{array}{l}\text { Heat stress } \\
\text { of residen- } \\
\text { tial areas } \\
\text { increase due } \\
\text { to heat wave }\end{array}$ & $\begin{array}{l}\text { Instability of } \\
\text { water resource } \\
\text { in agricultural } \\
\text { facilities } \\
\text { increase and } \\
\text { water quality } \\
\text { deterioration } \\
\text { due to drought } \\
\text { and tempera- } \\
\text { ture change }\end{array}$ & $\begin{array}{l}\text { Aquatic } \\
\text { organisms' } \\
\text { heat stress } \\
\text { increase due } \\
\text { to heat wave }\end{array}$ & $\begin{array}{l}\text { Habitats of } \\
\text { protected } \\
\text { plants reduc- } \\
\text { tion due to } \\
\text { temperature } \\
\text { increase }\end{array}$ & $\begin{array}{l}\text { Changes in } \\
\text { consumers' } \\
\text { consumption } \\
\text { patterns due } \\
\text { to climate } \\
\text { change }\end{array}$ & $\begin{array}{l}\text { Population and } \\
\text { habitats of } \\
\text { freshwater } \\
\text { organisms } \\
\text { (animals } \\
\text { and plants) } \\
\text { decrease } \\
\text { due to } \\
\text { temperature } \\
\text { increase and } \\
\text { precipitation } \\
\text { change }\end{array}$ & $\begin{array}{l}\text { Damage to } \\
\text { aquaculture } \\
\text { increase due } \\
\text { to heat wave, } \\
\text { cold wave, } \\
\text { hypoxiciza- } \\
\text { tion, and } \\
\text { typhoon }\end{array}$ \\
\hline 9 & $\begin{array}{l}\text { Cardiovascu- } \\
\text { lar diseases } \\
\text { increase } \\
\text { due to } \\
\text { temperature } \\
\text { fluctuation } \\
\text { increase }\end{array}$ & $\begin{array}{l}\text { Fire risk } \\
\text { increase in } \\
\text { residential } \\
\text { areas caused } \\
\text { by forest fire } \\
\text { due to the } \\
\text { number of } \\
\text { drought days } \\
\text { increase }\end{array}$ & $\begin{array}{l}\text { Flood response- } \\
\text { ability of } \\
\text { agricultural } \\
\text { water facilities } \\
\text { decrease due } \\
\text { to precipita- } \\
\text { tion increase }\end{array}$ & $\begin{array}{l}\text { Groundwater } \\
\text { recharge rate } \\
\text { decrease due } \\
\text { to tempera- } \\
\text { ture increase } \\
\text { and drought }\end{array}$ & $\begin{array}{l}\text { The incidence } \\
\text { and size of } \\
\text { forest fires } \\
\text { increase due } \\
\text { to drought }\end{array}$ & $\begin{array}{l}\text { Damage to tour- } \\
\text { ism resources } \\
\text { increase due } \\
\text { to temperature } \\
\text { increase and } \\
\text { string wind }\end{array}$ & $\begin{array}{l}\text { Island ecosys- } \\
\text { tems changes } \\
\text { due to } \\
\text { temperature } \\
\text { increase and } \\
\text { sea level rise }\end{array}$ & $\begin{array}{l}\text { Fisheries } \\
\text { resources } \\
\text { changes due } \\
\text { to seawater } \\
\text { temperature } \\
\text { increase and } \\
\text { hypoxiciza- } \\
\text { tion }\end{array}$ \\
\hline
\end{tabular}




\begin{tabular}{|c|c|c|c|c|c|c|c|c|}
\hline \multirow[t]{2}{*}{ No. } & Health & Land & Agriculture & Water & Forest & Industry/energy & Ecosystem & $\begin{array}{l}\text { Ocean/fishery/ } \\
\text { coast }\end{array}$ \\
\hline & 12 & 12 & 14 & 10 & 12 & 12 & 11 & 10 \\
\hline 10 & $\begin{array}{l}\text { Mental health } \\
\text { diseases } \\
\text { increase due } \\
\text { to climate } \\
\text { disasters }\end{array}$ & $\begin{array}{l}\text { Early damage } \\
\text { phenomena } \\
\text { of paved } \\
\text { roads } \\
\text { increase due } \\
\text { to tempera- } \\
\text { ture variabil- } \\
\text { ity increase }\end{array}$ & $\begin{array}{l}\text { Use of agricul- } \\
\text { tural machin- } \\
\text { ery reduction } \\
\text { due to rainfall } \\
\text { days increase }\end{array}$ & $\begin{array}{l}\text { Vulnerability } \\
\text { of estuary } \\
\text { and coastal } \\
\text { water } \\
\text { management } \\
\text { increase due } \\
\text { to sea level } \\
\text { rise }\end{array}$ & $\begin{array}{l}\text { Occurrence of } \\
\text { landslides } \\
\text { increase due } \\
\text { to heavy rain }\end{array}$ & $\begin{array}{l}\text { Wind power } \\
\text { generation } \\
\text { variability } \\
\text { intensification } \\
\text { and changes } \\
\text { of wind power } \\
\text { resource areas } \\
\text { due to temper- } \\
\text { ature increase, } \\
\text { precipitation } \\
\text { increase, } \\
\text { wind pattern } \\
\text { changes }\end{array}$ & $\begin{array}{l}\text { Wetland area } \\
\text { decrease } \\
\text { and biologic } \\
\text { changes due } \\
\text { to climate } \\
\text { change }\end{array}$ & $\begin{array}{l}\text { Changes in } \\
\text { fishery } \\
\text { environment } \\
\text { due to marine } \\
\text { climate } \\
\text { change }\end{array}$ \\
\hline 11 & $\begin{array}{l}\text { Water-borne } \\
\text { diseases } \\
\text { increase due } \\
\text { to tempera- } \\
\text { ture increase }\end{array}$ & $\begin{array}{l}\text { Risk of defor- } \\
\text { mation and } \\
\text { derailment of } \\
\text { railway rails } \\
\text { increase due } \\
\text { to heat wave }\end{array}$ & $\begin{array}{l}\text { Cropping } \\
\text { systems } \\
\text { change due to } \\
\text { temperature } \\
\text { increase and } \\
\text { rainfall days } \\
\text { change }\end{array}$ & & $\begin{array}{l}\text { Turbidity and } \\
\text { sediments of } \\
\text { forest stream } \\
\text { increase due } \\
\text { to heavy rain }\end{array}$ & $\begin{array}{l}\text { Stability of } \\
\text { power plants } \\
\text { weaken due to } \\
\text { tidal wave and } \\
\text { sea level rise }\end{array}$ & $\begin{array}{l}\text { Ecosystem } \\
\text { change due } \\
\text { to extreme } \\
\text { weather } \\
\text { events }\end{array}$ & \\
\hline 12 & $\begin{array}{l}\text { Mediator } \\
\text { diseases } \\
\text { increase due } \\
\text { to tempera- } \\
\text { ture increase }\end{array}$ & $\begin{array}{l}\text { Damage to } \\
\text { port facilities } \\
\text { and airport } \\
\text { facilities } \\
\text { increase and } \\
\text { suspension } \\
\text { of operations } \\
\text { increase due } \\
\text { to abnormal } \\
\text { weather } \\
\text { events }\end{array}$ & $\begin{array}{l}\text { Crop cultivation } \\
\text { area change } \\
\text { due to tem- } \\
\text { perature and } \\
\text { precipitation } \\
\text { increase }\end{array}$ & & $\begin{array}{l}\text { Forest stream } \\
\text { water quality } \\
\text { deterioration } \\
\text { and dry- } \\
\text { ing due to } \\
\text { drought }\end{array}$ & $\begin{array}{l}\text { Transmission } \\
\text { and substa- } \\
\text { tion efficiency } \\
\text { decrease } \\
\text { and damage } \\
\text { to facilities } \\
\text { increase due } \\
\text { to temperature } \\
\text { increase, heat } \\
\text { wave, heavy } \\
\text { rain, and } \\
\text { strong wind }\end{array}$ & & \\
\hline 13 & & & $\begin{array}{l}\text { Crop productiv- } \\
\text { ity quality } \\
\text { decrease due } \\
\text { to temperature } \\
\text { increase }\end{array}$ & & & & & \\
\hline 14 & & & $\begin{array}{l}\text { Energy con- } \\
\text { sumption } \\
\text { of livestock } \\
\text { barns increase } \\
\text { due to heat } \\
\text { wave and cold } \\
\text { wave }\end{array}$ & & & & & \\
\hline
\end{tabular}

Acknowledgements This paper is based on the results of the research work "Mainstreaming adaptation policies-Establishing a risk list considering the impact of climate change" (2019-005-02) conducted by the Korea Environment Institute (KEI) upon the request of the Korea Ministry of Environment and "Development of Integrated Model for Climate Change Adaptation" conducted by Korea Environment Institute (KEI) with the funding by the Korea Ministry of Environment (MOE) as "'Climate Change Correspondence Program (2014001310006)".

Open Access This article is licensed under a Creative Commons Attribution 4.0 International License, which permits use, sharing, adaptation, distribution and reproduction in any medium or format, as long as you give appropriate credit to the original author(s) and the source, provide a link to the Creative Commons licence, and indicate if changes were made. The images or other third party material in this article are included in the article's Creative Commons licence, unless indicated otherwise in a credit line to the material. If material is not included in the article's Creative Commons licence and your intended use is not permitted by statutory regulation or exceeds the permitted use, you will need to obtain permission directly from the copyright holder. To view a copy of this licence, visit http://creativecommons.org/licenses/by/4.0/.

\section{References}

Adger WN et al (2018) Advances in risk assessment for climate change adaptation policy. Phil Trans R Soc A 376:2121 
Berrang-Ford L et al (2011) Are we adapting to climate change? Glob Environ Change 21(1):25-33

Berrang-Ford L et al (2019) Tracking global climate change adaptation among governments. Nat Clim Change 9(6):440-449

Brown I (2015) Comparative risk assessment to inform adaptation priorities for the natural environment: observations from the first UK climate change risk assessment. Climate 3(4):937-963

Brown K et al (2018) Turning risk assessment and adaptation policy priorities into meaningful interventions and governance processes. Phil Trans R Soc A 376:2121

Buth $M$ et al (2015) Germany's vulnerability to climate change summary. Umweltbundesamt, Dessau-Roßlau

Buth M et al (2017) Guidelines for climate impact and vulnerability assessments: recommendations of the Interministerial Working Group on adaptation to climate change of the German Federal Government. Umweltbundesamt, Dessau-Roßlau

Byrd III DM, Cothern RC (2000) Introduction to risk analysis: a systematic approach to science-based decision making. Government Institutes

CCC (2017a) Progress in preparing for climate change: 2017 report to Parliament. Climate Change Committee

CCC (2017b) UK climate change risk assessment 2017. Climate Change Committee

CCC (2021) Independent assessment of UK climate risk. Climate Change Committee

Dawson RJ et al (2018) A systems framework for national assessment of climate risks to infrastructure. Phil Trans R Soc A 376:2121

Dewey A, Drahota A (2016) Introduction to systematic reviews: online learning module. Cochrane Training. https://training.cochrane. org/interactivelearning/module-1-introduction-conducting-syste matic-reviews

EEA (2018) National climate change vulnerability and risk assessments in Europe, 2018. European Environment Agency

European Commission (2010) Risk assessment and mapping guidelines for disaster management. Commission Staff Working Paper, SEC (2010) 1626 final, Brussels

European Commission (2013) Guidelines on developing adaptation strategies. Staff working document, 134
Feng A, Chao Q (2020) An overview of assessment methods and analysis for climate change risk in China. Phys Chem Earth Parts A/B/C 117:102861

Ford JD, Berrang-Ford L (2011) Climate change adaptation in developed nations: from theory to practice, vol 42. Springer Science \& Business Media, Berlin

IPCC (2007) Climate change 2007: impacts, adaptation and vulnerability, 4th assessment report. IPCC

IPCC (2012) IPCC special report on managing the risks of extreme events and disasters to advance climate change adaptation (SREX). IPCC

IPCC (2014) Climate change 2014: impacts, adaptation and vulnerability, 5th assessment report. IPCC

Korea Government (2015) 제2차 국 가 기후변화 적응 대책 (20162020). Korea Government

MoE and NIER (2014) Korean climate change assessment report. Ministry of Environment Korea

Morgan MG et al (1990) Uncertainty: a guide to dealing with uncertainty in quantitative risk and policy analysis. Cambridge University Press, Cambridge

Papathoma-Köhle M et al (2016) A common methodology for risk assessment and mapping of climate change related hazardsimplications for climate change adaptation policies. Climate 4(1):8

Petticrew M, Roberts H (2006) Systematic reviews in the social sciences: a practical guide. Blackwell, Oxford

Preyssl C et al (1999) Risk management at ESA. ESA Bull 97:64-68

Sin S et al (2017) Support for monitoring and evaluation of the 2nd national climate change adaptation policy. Korea Environment Institute

Song Y et al (2019) 기후변화 영향을 고려한 리스크 목록 구축, Korea Environment Institute

Spires M et al (2014) Barriers to implementing planned communitybased adaptation in developing countries: a systematic literature review. Clim Dev 6(3):277-287

Tonmoy FN et al (2018) An investigation of coastal climate change risk assessment practice in Australia. Environ Sci Policy 80:9-20

WRI (2009) The national adaptive capacity framework: key institutional functions for a climate change. WRI 